\title{
Call for Papers on Aspects of Violence and Psychiatric Training
}

Derek Puddester M.D.

McMaster University, Ontario, Canada

Follow this and additional works at: https://jdc.jefferson.edu/jeffjpsychiatry

Part of the Psychiatry Commons

Let us know how access to this document benefits you

\section{Recommended Citation}

Puddester, Derek M.D. (1999) "Call for Papers on Aspects of Violence and Psychiatric Training," Jefferson Journal of Psychiatry. Vol. 14 : Iss. 2 , Article 3.

DOI: https://doi.org/10.29046/JJP.014.2.005

Available at: https://jdc.jefferson.edu/jeffjpsychiatry/vol14/iss2/3

This Article is brought to you for free and open access by the Jefferson Digital Commons. The Jefferson Digital Commons is a service of Thomas Jefferson University's Center for Teaching and Learning (CTL). The Commons is a showcase for Jefferson books and journals, peer-reviewed scholarly publications, unique historical collections from the University archives, and teaching tools. The Jefferson Digital Commons allows researchers and interested readers anywhere in the world to learn about and keep up to date with Jefferson scholarship. This article has been accepted for inclusion in Jefferson Journal of Psychiatry by an authorized administrator of the Jefferson Digital Commons. For more information, please contact: JeffersonDigitalCommons@jefferson.edu. 


\title{
Call for Papers on Aspects of Violence and Psychiatric Training
}

\author{
Derek Puddester, M.D.
}

Discussion of violence is not new to the psychiatric profession, nor to those just entering their training. However, resident well-being has taken a strong place on the national agenda and many organizations, including the American Psychiatric Association (APA), are looking for ways to address the issue.

The Committee of Residents and Fellows of the APA is working with a number of stakeholders in psychiatric education on the theme of aspects of violence in training, including the APA Council on Medical Education and Career Development and the Task Force on Violence, the American Association of Directors of Psychiatry Residency Training, and the American Medical Association-Resident Physician Section. One of our current projects is to develop a curricula on violence for consideration by programs, and to review existing strategies for training residents to assess and manage aspects of violence.

We now turn to the readers of The Jefferson Journal of Psychiatry and call for expertise in this area. The fall edition of the Journal will have a section on violence and psychiatric training, and we call for submissions on this theme. Submissions may include personal narratives, literature reviews, case presentations, or more formalized research reports (surveys, assessment of educational interventions, and so on). Already published examples on this theme can be viewed on the APA's Resident Webpage at http://www.psych.org.

Guidelines for submission are elsewhere in this issue, and the deadline is August 31, 1999. The Journal looks forward to publishing this special edition and feels that it may contribute to the development of useful and effective training guidelines in the domain of violence. 